\title{
ANALISIS HUKUM TERHADAP FAKTOR-FAKTOR YANG MELATARBELAKANGI TERJADINYA NIKAH SIRRI DAN DAMPAKNYA TERHADAP PEREMPUAN (ISTRI) DAN ANAK-ANAK
}

\author{
Siti Ummu Adillah \\ Fakultas Hukum Universitas Islam Sultan Agung Semarang \\ E-mail: adillah19@ymail.com
}

\begin{abstract}
Sirri marriage reality is like an iceberg phenomenon, many occur in society, but the tappears only small surface and publicized when the perpetrator of public officials or public figures. The negative impact of sirri marriage experienced by many women (wives) and children if her husband is not responsible. The factors underlying the community do sirri marriage is due to economic factors, factors not old enough, factor bond department/work or school, it was thought that the marriage valid according the religion, recording the only orderly administration, pregnant outside of marriage due to promiscuity, lack of understanding and awareness of marriage records, social factors, the difficulty of the rule of polygamy and the persistence of people who do sirri marriage because no one wants to take firm action against perpetrators of irresponsible. While positive and negative impact on women sirri marriage (wife) and children legally is actually having an impact for husbands, wives and children, both in terms of positive or negative side, its just not comparable to the positive side of negative impact and judging from the many cases, the negative side more experienced women (wives) and children than those experienced by husbands.
\end{abstract}

Keywords: sirri marriage, impact, woman (wife), children

\begin{abstract}
Abstrak
Realitas perkawinan sirri adalah seperti fenomena gunung es, banyak terjadi di masyarakat, tetapi hanya kecil muncul ke permukaan dan umumnya dipublikasikan ketika pelaku pejabat publik atau tokoh masyarakat. Dampak negatif dari perkawinan sirri dialami oleh banyak wanita (isteri) dan anakanak jika suaminya tidak bertanggung jawab. Faktor-faktor yang mendasari masyarakat melakukan perkawinan sirri adalah karena faktor ekonomi, belum cukup umur, ikatan dinas/kerja atau sekolah, mereka berpikir bahwa pernikahan sirri sah menurut agama, dan pencatatan hanya masalah administrasi saja; daripada hamil di luar nikah akibat pergaulan bebas, kurangnya pemahaman dan kesadaran pentingnya pencatatan pernikahan, faktor-faktor sosial, sulitnya aturan poligami, dan tidak adanya tindakan tegas terhadap pelaku. Pernikahan sirri membawa dampak positif dan negatif bagi suami, isteri dan anak-anak. Sisi negatifnya tidak sebanding dengan sisi positifnya terlihat dari banyaknya kasus yang terjadi, dimana sisi negatifnya banyak dialami wanita (isteri) dan anak-anak daripada yang dialami suami.
\end{abstract}

Kata kunci: nikah sirri, dampak, wanita (isteri), anak

\section{Pendahuluan}

Nikah sirri atau nikah dibawah tangan yang terjadi di masyarakat adalah masalah yang sudah lama terjadi. Nikah sirri merupakan nikah rahasia, atau pernikahan yang tidak di ketahui oleh orang tuanya, seperti kawin lari, nikah secara diam-diam, nikah yang tidak di ketahui oleh orang banyak dan tidak diketahui oleh pemerintah yang sah, dalam artian per- nikahannya tidak dicatatkan di Pegawai Pencatat Nikah. ${ }^{1}$

Kasus nikah sirri yang pernah mencuat misalnya kasus artis Angel Lelga, yang dikabarkan telah melakukan nikah sirri untuk ketiga

Khoirul Hidayah, "Dualisme Hukum Perkawinan di Indonesia (Analisis Sosiologi Hukum Terhadap Praktik Nikah Sirri)", Jurnal Perspektif Hukum Vol. 8 (1) Mei 2008 Universitas Hang Tuah Surabaya, hlm. 90 
kalinya. Pertama dengan si Raja Dangdut Rhoma Irama, kedua dengan pengusaha penerbangan HM Rusli, dan yang ketiga dengan Abdul Rahman Widi alias Aman Jagau seorang pengusaha batu bara, yang tak lain juga suami penyanyi dangdut Cucu Cahyati. Kasus tersebut berbuntut panjang karena adanya saling menuntut antara istri sah dan sekaligus istri pertama Aman Jagau, Rina Rahmasari, yang menuntut Aman Jagau, Cucu Cahyati, dan Angel Lelga dengan pasal perzinahan.

Kali ini Angel Lelga menuai perkara akibat dia membantah pernikahan sirrinya dengan Aman. Angel tidak mengakui kalau dia telah menikah sirri dengan Aman. Sementara Aman mengatakan telah menikah sirri dengan Angel pada tanggal 1 Februari 2007 di hotel Permata Inn, Kota Banjar Baru, Kalimantan Selatan. Aman mempunyai saksi sebagai bukti dalam acara pernikahan yang tanpa dokumentasi itu, berupa 16 orang tamu yang hadir dalam acara tersebut dan tidak ada bukti lain. Kemudian Aman juga menuntut Angel terkait dengan tuduhan penipuan dan penggelapan uang $\mathrm{Rp}$ 150 juta yang diberikan Aman kepada Angel. Sampai bulan Mei 2007, kasus ini masih ditangani pihak kepolisian.

Terlepas dari benar tidaknya berita pernikahan Angel dan Aman, realitasnya pernikahan sirri ibarat fenomena gunung es, banyak terjadi di masyarakat, akan tetapi yang muncul kepermukaan hanyalah sebagian kecil saja. Pernikahan sirri yang sering muncul beritanya, adalah yang pelakunya para artis dan pejabat publik. Seperti kasus perselingkuhan antara politikus Yahya Zaini dengan artis Maria Eva, mereka berdalih atau memang sesungguhnya telah melakukan nikah sirri.

Selama ini nikah sirri lebih cenderung merugikan pihak perempuan (istri) dan anak atau anak-anak yang lahir dari pernikahan sirri. Hal ini dikarenakan seorang suami mempunyai kewajiban memberikan nafkah pada istri dan anak-anaknya yang dilahirkan dari pernikahan sirri, namun karena tidak adanya perjanjian hitam diatas putih (bukti secara tertulis, terutama surat nikah) maka dengan mudah suami mengingkari kewajibannya atau bahkan meninggalkan atau menelantarkan begitu saja istri dan anak hasil nikah sirrinya, sementara istri dan anak tidak dapat berbuat banyak karena tidak adanya bukti otentik.

Pada akhir bulan Maret 2007 terjadi kasus nikah sirri yang berakhir di kantor polisi, seorang istri yang telah dinikah sirri mengalami tindak kekerasan dalam rumah tangga akibat perlakuan dari suaminya. Suami dilaporkan ke polisi dan akhirnya di penjara, sedangkan istri dalam keadaan hamil tua dan tidak bekerja, dan sudah tujuh (7) bulan tidak diberi nafkah.

Kasus nikah sirri yang berdampak pada kekerasan dalam rumah tangga banyak terjadi, akan tetapi sangat sedikit yang sampai terpublikasikan. Meskipun banyak dampak negatif yang terjadi terutama pada perempuan (istri) dan anak, pernikahan sirri masih sering dilakukan masyarakat. Karenanya, kajian nikah sirri dalam konteks hukum Indonesia amat penting untuk dilakukan.

Mencermati hal diatas, maka tulisan ini dimaksudkan untuk mengkaji tentang faktorfaktor yang melatarbelakangi masyarakat melakukan nikah sirri dan dampak positif serta negatif dari pernikahan sirri terhadap perempuan (istri) dan anak-anak secara hukum.

\section{Pembahasan}

\section{Faktor-Faktor yang Melatarbelakangi Masyara-} kat Melakukan Nikah Sirri.

Nikah sirri dilakukan pada umumnya karena ada sesuatu yang dirahasiakan, atau karena mengandung suatu masalah. Oleh karena nikah sirri mengandung masalah, maka masalah itu akan berakibat menimpa pada orang yang bersangkutan, termasuk anak-anak yang dilahirkan dari pernikahan sirri. ${ }^{2}$

\footnotetext{
Lihat Widiastuti, "Beberapa Faktor Penyebab Pasangan Suami Isteri Melakukan Pernikahan di Bawah Tangan", Jurnal Eksplorasi Vol. XX (1) tahun 2008, LPPM Slamet Riyadi, hlm. 78-89
} 
Teori Receptio In Complexu diintrodusir Lodewijk Willem Christian Van Den Berg (18231927) yang menyatakan, hukum Islam telah diterima dalam masyarakat Indonesia secara keseluruhan. Lebih lanjut, Van Den Berg menyatakan, hukum Islam telah diterima dalam hukum keluarga dan hukum waris Islam di Jawa dan Madura dengan beberapa penyimpangan. ${ }^{3}$ Kawin Mut'ah (kawin kontrak) dan kawin Sirri (kawin dibawah tangan) menjadi bagian dari hukum keluarga. Namun, penyimpangan tentang pemahaman kawin mut'ah dan sirri belum menjadi pembahasannya yang mendalam. ${ }^{4}$

Snouck Hurgrounje menentang teori Receptie In Complexu, dan menyatakan, hukum Islam belum diterima oleh masyarakat yang .berlaku dalam masyarakat hukum adat, pengaruh hukum Islam tersebut baru dapat mempunyai kekuatan hukum jika benar-benar telah diterima oleh hukum adat, kemudian Islam menjadi hukum adat; dan teori ini dikenal dengan teori Receptie. ${ }^{5}$

Teori di atas dalam praktiknya berpengaruh terhadap perkawinan. Salah satu bentuk yang dipengaruhi adalah nikah sirri atau tidak mencatatkan pernikahannya di KUA atau KCS. Adapun faktor-faktor yang melatarbelakangi terjadinya nikah sirri adalah sebagai berikut.

Pertama, faktor ekonomi. Faktor ekonomi diantaranya karena biaya administrasi pencatatan nikah, yaitu sebagian masyarakat khususnya yang ekonomi menengah ke bawah merasa tidak mampu membayar administrasi pencatatan yang kadang membengkak dua kali

3 Bandingkan dengan Linda Firdawaty, "Perlindungan Hukum Bagi Anak Karena Perkawinan Yang Fasakh Karena Melanggar Larangan Perkawinan”, Jurnal kajian Hukum Al-Adalah Vol. 7 (1) Juni 2008, IAIN Raden Intan Lampung, hlm. 28-36

4 Liha Abdul Ghofur Anshori, "Orientasi Nilai Filsafat Hukum Keluarga; Refleksi Undang-Undang Nomor 1 tahun 1974 tentang Perkawinan”, Jurnal Mimbar Hukum 18 (1) Februari 2006, FH UGM Yogyakarta, hlm. 1-16

5 Sajuti Talib,1996, Receptio A Contrario, Hubungan Hukum dan Tata Hukum Islam, Jakarta: Rajawali Grafindo, hlm. 214-218; Lihat Taufiqul Hulam, "Transformasi Hukum Islam Dalam Sistem Hukum Perkawinan Orang Sakai di Desa Mandiangin Kecamatan Minas Kabupaten Biak", Jurnal Hukum Respublica Vol. 5 (1) Tahun 2005, Universitas Lancang Kuning Pekanbaru, hlm. 1-11 lipat dari biaya resmi. ${ }^{6}$ Ada keluhan dari masyarakat bahwa biaya pencatatan pernikahan di KUA tidak transparan, berapa biaya sesungguhnya secara normatif. Oleh karena dalam praktik masyarakat yang melakukan perkawinan, di kenai biaya yang beragam.

Adanya kebiasaan yang terjadi di masyarakat, bahwa seorang mempelai laki-laki selain ada kewajiban membayar mahar, juga harus menanggung biaya pesta perkawinan yang cukup besar (meskipun hal ini terjadi menurut adat kebiasaan), di daerah Jawa Tengah selain mahar ada juga biaya untuk serah-serahan (pemberian biaya untuk penyelenggaraan pernikahan), alasan ini pula yang menjadi penyebab laki-laki yang ekonominya belum mapan lebih memilih menikah dengan cara diam-diam, yang penting halal alias ada saksi tanpa harus melakukan pesta seperti umumnya pernikahan.

Kedua, faktor belum cukup umur. Nikah sirri dilakukan karena adanya salah satu calon mempelai belum cukup umur. Kasus ini terjadi disebabkan alasan ekonomi juga, dimana orang tua merasa kalau anak perempuannya sudah menikah, maka beban keluarga secara ekonomi menjadi berkurang, karena anak perempuannya sudah ada yang nanggung/ngurusi yaitu suaminya. Salah satu contoh kasus yang ramai terjadi adalah kasus nikah sirrinya Syekh Puji (Pujiono) dengan Ulfah yang masih anak-anak di Kabupaten Semarang.

Ketiga, faktor ikatan dinas/kerja atau sekolah. Adanya ikatan dinas/kerja atau peraturan sekolah yang tidak membolehkan menikah karena dia bekerja selama waktu tertentu sesuai dengan perjanjian yang sudah disepakati, atau karena masih sekolah maka tidak boleh menikah dulu sampai lulus. Kalau kemudian menikah, maka akan dikeluarkan dari tempat kerja atau sekolah, karena dianggap sudah melanggar aturan.

Keempat, ada anggapan bahwa nikah sirri sah menurut agama, pencatatan itu hanya tertib administrasi. Menurut Ahmad Rofiq, adanya anggapan yang menyatakan bahwa

6 Admin, Hukum Nikah Sirri, 04 April 2010, http:// dewandakwahjakarta.or.id/index.php/buletin/ april10/ 140-april4.html, akses tanggal 6 Februari 2011 
sahnya sebuah perkawinan hanya didasarkan pada norma agama sebagaimana disebut dalam Undang-undang Nomor 1 Tahun 1974 tentang Perkawinan Pasal 2 ayat (1) dan ayat (2) yang menyebutkan bahwa pencatatan perkawinan tidak memiliki hubungan dengan sah tidaknya sebuah perkawinan dipraktekkan sebagian masyarakat dengan menghidupkan praktek nikah sirri tanpa melibatkan petugas Pegawai Pencatat Nikah (PPN). Fenomena ini banyak terjadi pada sebagian masyarakat yang masih berpegang pada hukum perkawinan yang figh sentris. $^{7}$

Kelima, hamil diluar nikah, sebagai efek pergaulan bebas. Akibat dari pergaulan bebas antara laki-laki dan perempuan, yang tidak lagi mengindahkan norma dan kaidah-kaidah agama adalah terjadinya hamil diluar nikah. Kehamilan yang terjadi diluar nikah tersebut, merupakan aib bagi keluarga yang akan mengundang cemoohan dari masyarakat. Dari sanalah orang tua menikahkan secara sirri anaknya dengan laki-laki yang menghamilinya dengan alasan menyelamatkan nama baik keluarga dan tanpa melibatkan petugas PPN, tetapi hanya dilakukan oleh mualim (ada istilah nikah secara kiyai) tanpa melakukan pencatatan.

Keenam, kurangnya pemahaman dan kesadaran masyarakat tentang pencatatan pernikahan. Dengan pemahaman masyarakat yang sangat minim tentang pentingnya pencatatan pernikahan, akibatnya mempengaruhi masyarakat tetap melaksanakan pernikahan sirri. Adanya anggapan bahwa perkawinan yang dicatat dan tidak dicatat sama saja. Padahal telah dijelaskan dalam Undang-undang Perkawinan yaitu: "Tiap-tiap perkawinan dicatat menurut peraturan yang berlaku (Pasal 2 ayat (1) Undang-undang nomor 1 tahun 1974). Bagi mereka yang melakukan perkawinan menurut agama Islam, pencatatan dilakukan di Kantor Urusan Agama (KUA). Sedang bagi yang beragama

\footnotetext{
Ahmad Rofiq, 2000, Hukum Islam di Indonesia, Jakarta:
} PT. Raja Grafindo Persada, hlm. 109.
Katholik, Kristen, Budha, Hindu, pencatatan itu dilakukan di Kantor Catatan Sipil (KCS)."

Ketujuh, faktor sosial. Faktor sosial, yaitu masyarakat sudah terlanjur memberikan stigma negatif kepada setiap orang (laki-laki) yang menikah lebih dari satu (berpoligami), maka untuk menghindari stigma negatif tersebut, seseorang tidak mencatatkan pernikahannya kepada lembaga resmi.

Kedelapan, sulitnya aturan berpoligami. Untuk dilakukannya pernikahan yang kedua, ketiga dan seterusnya (poligami) ada beberapa syarat yang harus dipenuhi, sesuai dengan syarat poligami yang dijelaskan dalam Pasal 5 Undang-undang No 1 tahun 1974 yaitu harus mendapat izin dan persetujuan dari istri sebelumnya. Hal ini diharapkan dapat memperkecil dilakukannya poligami bagi laki-laki yang telah menikah tanpa alasan tertentu. Dan karena sulit untuk mendapatkan ijin dari istri, maka akhirnya suami melakukan nikah secara diamdiam atau nikah sirri. ${ }^{8}$

Kesembilan, masih adanya masyarakat yang melakukan nikah sirri karena tidak ada yang mau mengambil tindakan yang tegas. Dalam Peraturan Pemerintah Nomor 9 Tahun 1975 Tentang Pelaksanaan Undang-undang Nomor 1 Tahun 1974 Tentang Perkawinan Pasal 45 menyatakan:

(1) Kecuali apabila ditentukan lain dalam peraturan perundang-undangan yang berlaku, maka:

a. Barang siapa yang melanggar ketentuan yang diatur dalam Pasal 3, 10 ayat (3), 40 Peraturan Pemerintah ini dihukum dengan hukuman denda setinggi-tingginya Rp. 7.500 (tujuh ribu lima ratus rupiah);

b. Pegawai Pencatat yang melanggar ketentuan yang diatur dalam Pasal $6,7,8,9,10$ ayat (1), 11, 13, 44 Peraturan Pemerintah ini dihukum dengan hukuman kurungan selama lamanya 3 (tiga) bulan atau denda

8 Heru Susetyo, "Revisi Undang-Undang Perkawinan", Jurnal Lex Jurnalica 4 (2) April 2007 Universitas Indonusa Esa Unggul, hlm. 73 
setinggi-tingginya Rp. 7.500 (tujuh ribu lima ratus rupiah).

(2) Tindak pidana yang dimaksud dalam ayat (1) di atas merupakan pelanggaran

Pegawai Pencatat Nikah atau aparat penegak hukum mestinya memberikan sanksi secara tegas terhadap pelaku nikah sirri yang tidak bertanggungjawab dan mengabaikan kewajibannya, hal ini untuk membuat jera pelaku, meskipun sanksi yang ada cukup ringan.

Pelaku nikah sirri yang tidak bertanggung jawab dan mengabaikan kewajibannya yang diproses secara hukum, akan memberikan gambaran atau contoh bahwa nikah sirri itu berdampak buruk baik terhadap suami, isteri maupun anak-anaknya. Sebaliknya bila tidak diambil tindakan hukum, maka masyarakat menganggap tidak masalah melakukan nikah sirri dan masyarakat akan terus dan banyak yang tetap melakukan nikah sirri.

Dampak Positif dan Negatif Pernikahan Sirri Terhadap Perempuan (Istri), dan Anak-anak Secara Hukum.

Sebenarnya pernikahan sirri memiliki dampak bagi suami, isteri maupun anak-anak, baik dari sisi positif maupun sisi negatif, hanya saja sisi positf tidak seimbang dengan dampak negatifnya dan kalau dilihat dari banyak kasus, sisi negatifnya lebih banyak dialami para perempuan (istri) dan anak-anak daripada yang dialami suami.

Berikut ini akan diuraikan beberapa hal sebagai dampak dilakukannya pernikahan sirri, baik dari sisi positif maupun sisi negatif bagi perempuan (istri) dan anak-anak secara hukum. Dampak positif pernikahan sirri terhadap perempuan (istri) dan anak-anak secara hukum dapat diperinci sebagai berikut.

Pertama, hak-hak individu dapat tertutupi. Kepentingan-kepentingan pihak-pihak yang melatarbelakangi dilakukannya pernikahan sirri dapat tertutupi, misalnya Karena hamil diluar nikah, maka nikah sirri dilakukan sebagai upaya agar aib dalam keluarganya tertutupi sehingga masyarakat tidak mengetahui seputar kehamilannya yang terjadi diluar nikah.
Demikian pula misalnya karena adanya ikatan dinas atau masih sekolah. Karena terikat dengan perjanjian kerja, sementara ada hal mendesak seseorang harus menikah, maka dilakukanlah nikah sirri, begitu pula dengan yang masih sekolah, karena suatu keperluan, salah satu calon mempelai mau studi ke luar negeri, maka nikah sirri dilakukan untuk mengikat kedua mempelai dan keluarga.

Kedua, hilangnya kekhawatiran perzinahan. Hilangnya kehwatiran berzina, alasan ini yang kadang melatarbelakangi dilakukannya nikah sirri, baik yang terjadi pada orang dewasa (dimana laki-lakinya sudah terikat perkawinan atau sudah punya istri) maupun remaja yang masih sekolah atau kuliah. Dari pada terjerumus ke dalam perzinahan atau berbuat dosa, maka solusi yang dianggap terbaik, yaitu dengan melakukan nikah sirri.

Perkembangannya yang terjadi di kalangan remaja, khususnya para mahasiswa tertentu yang tergabung dalam kelompok-kelompok pengajian tertentu pula, kalau ada sepasang remaja yang merasa sudah memiliki kecocokan dan daripada terjerumus kepada perzinahan, maka mereka akan menikah sirri atau dinikahkan secara sirri (tidak dicatat dalam KUA) oleh "guru" mereka. Hal ini dilakukan karena berbagai alasan, pertama kalau meminta restu orang tua mereka, khawatir tidak diperbolehkan karena mereka masih kuliah dan takut mengganggu kuliah, kedua karena alasan ekonomi mengingat kebutuhan mereka masih bergantung pada orang tua mereka, dan yang pasti (alasan ketiga) ada pertimbangan takut berbuat dosa/zina. Dengan menikah sirri, maka tidak ada kehawatiran dari masing-masing pihak dan mereka merasa pernikahan yang dilakukan tidak melanggar agama.

Pernikahan sirri banyak berdampak negatif terhadap perempuan (istri) dan anakanak, bila suami tidak bertanggungjawab, sebaliknya bagi laki-laki (suami) hampir tidak ada dampak yang mengkhawatirkan atau merugikan, yang terjadi justru menguntungkan lakilaki yitu jika suami mau lari dari tanggung jawab atau mengaku masih single jika mau ni- 
kah lagi. Dampak negatif terhadap perempuan (istri) secara hukum adalah sebagai berikut.

Pertama, tidak diakui sebagai istri, karena perkawinan dianggap tidak sah. Oleh karena perempuan yang nikah sirri tidak mempunyai bukti berupa surat nikah, maka akibatnya bila suami tidak bertanggungjawab, ia tidak dianggap sebagai istri, meski perkawinan dilakukan menurut agama dan kepercayaan, namun di mata negara nikah sirri dianggap tidak sah jika belum dicatat oleh Kantor Urusan Agama (KUA) atau Kantor Catatan Sipil (KCS).

Kedua, terabaikannya hak dan kewajiban. Seorang suami yang melakukan nikah sirri mudah mengabaikan hak dan kewajibannya baik secara lahir maupun batin dan mudah untuk tidak bertanggungjawab sebagai seorang suami terhadap istri yang dinikahinya secara sirri karena tidak ada alat bukti berupa surat nikah, sebagai bukti autentik.

Ketiga, tidak berhak atas nafkah, warisan dan pembagian harta bersama. Akibat lebih jauh dari nikah sirri adalah, istri tidak berhak menuntut nafkah jika suaminya masih hidup dan tidak bertanggungjawab, tidak dapat menuntut warisan dari suaminya jika meninggal dunia, karena pernikahannya tidak pernah di anggap ada menurut hukum Indonesia, dan tidak dapat menuntut pembagian harta bersama jika terjadi perceraian, karena tidak ada bukti authentik yang menyatakan bahwa mereka telah nikah sirri. ${ }^{9}$

Keempat, tidak memberikan kepastian hukum. Pernikahan sirri, tidak memberikan kepastian hukum yaitu ketika terjadi sengketa hukum (misal mau melakukan perbuatan-perbuatan hukum seperti jual beli tanah atau rumah, mengajukan kredit ke bank, dan sebagainya) karena tidak adanya bukti authentik, sehingga pernikahannya tidak pernah dianggap ada menurut hukum Indonesia, selain itu nikah

9 Lihat Wiratni Ahmadi, "Hak dan Kewajiban Wanita Dalam keluarga Menurut Undang-Undang Nomor 1 Tahun 1974 tentang Perkawinan", Jurnal Hukum Pro justitia Vol. 26 (4) Oktober 2008 FH Unpar Bandung hlm. 371390 sirri rentan terhadap masalah kekerasan dalam rumah tangga, karena kalau suami tidak bertanggungjawab, dia bisa berlaku sewenangwenang. ${ }^{10}$

Kelima, menyulitkan untuk mengidentifikasi status seseorang sudah menikah atau belum. Nikah sirri atau pernikahan yang tidak disiarkan, atau dirahasiakan menyebabkan banyak orang yang tidak mengetahui identitas tentang status pasangan tersebut. Di dalam Islam ada perintah untuk mengumukan pernikahan. Hal ini bertujuan agar jika ada orang yang naksir atau menaruh hati, maka dia akan mundur karena orang yang ditaksirnya sudah menikah, sehingga jelas status orang tersebut yaitu sudah beristri atau sudah bersuami.

Keenam, adanya keresahan/kehawatiran, melaksanakan pernikahan sirri, dikarenakan tidak memiliki akta nikah. Mereka (suami istri) khawatir apabila bepergian jauh atau kemalaman dijalan mereka tidak dapat membuktikan bahwa mereka suami istri, sehubungan dengan banyaknya razia terhadap para tuna susila.

Ketujuh, sanksi sosial dari masyarakat terhadap pelaku nikah sirri. Adanya fitnah, risiko pernikahan sirri adalah timbulnya fitnah, masyarakat menggap bahwa perkawinan yang dilakuakan secara sirri merupakan upaya dirinya (pasangan yang menikah) untuk menutupi aib seputar kehamilan diluar nikah. Walaupun spekualsi tersebut belum tentu benar adanya atau ada hal-hal lain yang disembunyikan dan menjadikan masyarakat berprasangka buruk (su udzon).

Kedelapan, sulit bersosialisasi. Istri yang nikah sirri akan sulit bersosialisasi karena sering dianggap telah tinggal serumah dengan laklaki tanpa ikatan perkawinan (alias kumpul kebo) atau dianggap sebagai istri simpanan. Atas dasar itu, anjuran untuk mencatatkan pernikahan di lembaga pencatatan negara men-

10 Andrie Irawan, 2009, Fenomena Perkawinan Sirri Serta Dampaknya Bagi Perempuan dan Anak, Universitas Islam Indonesia Yogyakarta, http://www.docstoc.com/ docs/8436232/Dampak-Nikah-Siri-bagi-Perempuan-danAnak, akses tanggal 7 Januari 2011. 
jadi relevan, demi mewujudkan kemudahankemudahan bagi suami istri dan masyarakat serta untuk mencegah adanya stigma yang negatif terhadap pasangan nikah sirri.

Kesembilan, menyulitkan masyarakat untuk memberikan kesaksiannya, jika kelak ada persoalan-persoalan yang menyangkut kedua mempelai. Oleh karena nikah sirri (nikah diamdiam), maka banyak masyarakat yang tidak mengetahui kalau kedua mempelai sudah menikah, akibatnya bila terjadi perselisihan di antara pasangan nikah sirri atau terjadi penelantaran terhadap istri dan atau anak-anaknya secara ekonomi misalnya, maka masyarakat akan kesulitan untuk membatu atau memberikan kesaksian.

Kesepuluh, adanya anggapan poligami terhadap pelaku nikah sirri. Apabila ada pasangan yang melakukan nikah sirri, maka masyarakat akan menaruh kecurigaan. Masyarakat menganggap bahwa pernikahan sirri merupakan upaya untuk menutupi adanya poligami sehingga dilakukan nikah secara diam-diam, agar istri sebelumnnya atau istri pertamanya tidak mengetahui perihal poligami tersebut. Walaupun anggapan tersebut tidak benar adanya.

Dampak negatif perkawinan sirri bukan hanya diderita oleh perempuan (isteri), akan tetapi juga oleh anak-anak yang lahir dari perkawinan tersebut. Berikut dampak negatif terhadap anak-anak secara hukum yang lahir dari perkawinan tersebut.

Pertama, anak hanya mempunyai hubungan perdata dengan ibu dan keluarga ibu. Nikah sirri memiliki dampak negatif bagi status anak yang dilahirkan di mata hukum, yakni: status anak yang dilahirkan dianggap sebagai anak tidak sah. Konsekuensinya, anak hanya mempunyai hubungan perdata dengan ibu dan keluarga ibu. Artinya, si anak tidak mempunyai hubungan hukum terhadap ayahnya (Pasal 42 dan Pasal 43 Undang-undang No 1 tahun 1974, Pasal $100 \mathrm{KHI})$.

Status anak dalam akte kelahiran, di anggap sebagai anak luar nikah, sehingga hanya dicantumkan nama ibu yang melahirkannya. ${ }^{11}$ Dalam pembuatan akta kelahiran misalnya, anak hanya akan dicatat mengikuti ibunya karena pencatatan sipil untuk kelahiran anak mensyaratkan adanya surat nikah resmi dari Negara, ${ }^{12}$ sehingga hak identitasnya tidak akan diakui bahwa dia anak dari seorang ayah yang telah melakukan nikah sirri, maka nasabnya (bin atau bintinya) menjadi ikut ibunya.

Kedua, anak tidak berhak atas nafkah, warisan dan hak-hak lainnya. Sepanjang tidak ada pengingkaran dari ayahnya terhadap nikah sirri atau pelakunya bertanggungjawab, maka dalam hal pemberian nafkah atau hak-hak lainnya tidak ada persoalan. Namun jika terjadi pengingkaran atau ayahnya tidak bertanggung jawab dengan meninggalkan begitu saja anak hasil nikah sirri maka hal ini akan merugikan anak. Anak menjadi tidak berhak atas biaya kehidupan dan pendidikan, nafkah dan warisan dari ayahnya. Hak nafkah dan warisnya akan hilang karena anak tidak memiliki bukti apaapa, maka anak akan mendapat hak-haknya hanya dari ibunya.

Nikah sirri merugikan anak-anak di kemudian hari, karena untuk masuk sekolah harus ada akte kelahiran, sedangkan akte kelahiran bisa dibuat kalau ada surat nikah. Suami istri yang nikah sirri tidak mempunyai akte perkawinan atau surat nikah, maka akibatnya tidak bisa mempunyai kartu keluarga.

Ketiga, anak hasil nikah sirri rentan menjadi korban eksploitasi. Diantaranya, seperti pelacuran dan perdagangan anak. Oleh karena pada umumnya, anak-anak korban nikah sirri biasanya terlantar dan kurang terurus baik dari segi ekonomi, kesehatan, pendidikan maupun masa depannya. Itu terjadi, karena anak nikah sirri yang diasuh ibunya yang (misalnya) tidak mandiri secara ekonomi atau hanya dititipkan kepada orang tua di kampung dengan jaminan

\footnotetext{
11 Pemkab Tulung Agung, Yang Perlu Diketahui Tentang Nikah Siri atau Nikah Di Bawah Tangan,http://www. tulungagung.go.id/index.php/component/k2/itemlist/u ser/89 bagian hukum, di akses tanggal 11 Januari 2011

12 Kompas, http://www2.kompas.com/ver1 /Perempuan/ 0706/25/102054.htm, akses tanggal 6 Januari 2011
} 
kesehatan yang relatif rendah. Akibatnya, mereka menderita gizi buruk. ${ }^{13}$

Teori struktural fungsional Talcot Parsons menyatakan, perubahan dari masyarakat tradisional ke masyarakat yang lebih modern itu diikuti oleh adanya proses diferensiasi integrasi. Proses ini disebut dengan struktural fungsional. ${ }^{14}$ Oleh karena itu pertimbangan digunakannya teori struktural fungsional terfokus pada pengkajian permasalahan kawin sirri sebagaimana perkembangan dan tuntutan kehidupan modern pada satu sisi serta ketakutan akan berbuat zina pada sisi lain. Pada kasuskasus isteri tidak sehat atau tidak mempunyai keturunan, namun tak mau dicerai atau dimadu, atau demi status sosial, maupun ekono$\mathrm{mi}$, sampai pada alasan pemenuhan hasrat seks (libido) merupakan faktor-faktor pendorong yang mengakibatkan praktek kawin Sirri tetap berlangsung/terjadi.

Dapat ditambahkan, bahwa kebenaran anggapan itu dapat dipahami dari perspektif bekerjanya hukum di masyarakat yang bertolak dari ukuran moral dan tujuan tertentu. Pola tingkah laku individu di masyarakat terkait dengan nilai moral tertentu, oleh karena itu tingkah laku tersebut merupakan lembaga dan kenyataan atau realitas hukum yang ada di masyarakat.

\section{Penutup}

Simpulan

Banyak faktor yang menyebabkan seseorang melakukan nikah sirri atau tidak mencatatkan pernikahannya di KUA atau KCS. Faktor-faktor yang melatarbelakangi terjadinya nikah sirri adalah karena faktor ekonomi, belum cukup umur, ikatan dinas/kerja atau se-

13 Kedaulatan Rakyat, Nikah Siri Berdampak Buruk Pada Masa Depan Anak, http://www.krjogja.com/news/ detail/21438/www. krjgogja.com, akses tanggal 7 Januari 2011.

14 Lihat Teddy Anggoro, "Kajian Hukum Masyarakat Hukum Adat dan HAM Dalam Lingkup Negara Kesatuan Republik Indonesia", Jurnal Hukum dan Pembangunan Vol. 36 (4) Oktober-Desember 2006 FH UI Jakarta, hlm. 487-498 kolah, ada anggapan bahwa nikah sirri sah menurut agama, pencatatan itu hanya tertib administrasi, hamil diluar nikah akibat pergaulan bebas, kurangnya pemahaman dan kesadaran masyarakat tentang pencatatan pernikahan, faktor sosial, sulitnya aturan berpoligami dan karena tidak ada tindakan yang tegas.

Beberapa dampak dilakukannya pernikahan sirri, baik dari sisi positif maupun sisi negatif bagi perempuan dan anak-anak secara hukum. Pertama, dampak positif pernikahan sirri terhadap perempuan (istri) dan anak-anak secara hukum adalah hak-hak Individu dapat tertutupi dan hilangnya kekhawatiran perzinahan diantara pasangan pelaku nikah sirri sedangkan sisi positif bagi anak yang dilahirkan tidak ada; kedua, dampak negatif pernikahan sirri terhadap perempuan (istri) dan anak-anak secara hukum

Dampak terhadap perempuan (Istri) berupa tidak diakui sebagai istri karena perkawinan dianggap tidak sah, tidak memberikan kepastian hukum, terabaikannya hak dan kewajiban secara lahir maupun batin, tidak dapat menun-tut hak nafkah, warisan dan pembagian harta bersama, Istri yang nikah sirri akan sulit bersosialisasi dan dapat menimbulkan fitnah di masyarakat, serta menyulitkan masyarakat untuk memberikan kesaksiannya, jika kelak ada persoalan-persoalan hukum atau keluarga.

Dampak terhadap anak-anak berupa anak yang dilahirkan dari pernikahan sirri menyebabkan anak hanya mempunyai hubungan perdata dengan ibu dan keluarganya. Anak menjadi tidak berhak atas nafkah, warisan dan hak-hak lainnya seperti untuk masuk sekolah harus ada akte kelahiran, dan seterusnya. Anak hasil nikah sirri rentan menjadi korban eksploitasi.

\section{Rekomendasi}

Petugas Pencatat Nikah seperti KUA atau KCS atau lembaga terkait lainnya perlu melakukan sosialisasi tentang biaya pencatatan nikah. Bagi masyarakat tidak mampu membayar 
pencatatan perkawinannya sebaiknya ada dispensasi atau pembebasan biaya oleh negara. Budaya di masyarakat laki-laki harus menanggung biaya pernikahan, bisa dimusyawarahkan bersama-sama, agar tidak memberatkan pihak laki-laki, hal ini untuk meminimalisir pernikahan sirri karena faktor ekonomi.

Pemerintah perlu melakukan sosialisasi secara terus menerus tentang resiko nikah sirri, agar masyarakat tidak melakukan nikah sirri dan menghimbau untuk mencatatkan perkawinannya. Pemerintah perlu memberi sanksi yang tegas bagi pelaku nikah sirri yang tidak bertanggungjawab dan pihak-pihak yang telah membantu terjadinya nikah sirri yang berakibat buruk terhadap perempuan (istri) dan anak-anak.

\section{Daftar Pustaka}

Admin. Hukum Nikah Sirri. 04 April 2010. http://dewandakwahjakarta.or.id/index. php/buletin/april10/140-april4.html, akses tanggal 6 Februari 2011;

Ahmadi, Wiratni. "Hak dan Kewajiban Wanita Da-lam keluarga Menurut Undang-Undang Nomor 1 Tahun 1974 tentang Perkawinan". Jurnal Hukum Pro justitia. Vol. 26 No. 4. Oktober 2008. Bandung: FH Unpar;

Anggoro, Teddy. "Kajian Hukum Masyarakat Hukum Adat dan HAM Dalam Lingkup Negara Kesatuan Republik Indonesia". Jurnal Hukum dan Pembangunan. Vol. 36 No. 4. Oktober-Desember 2006. Jakarta: FH UI;

Anshori, Abdul Ghofur. "Orientasi Nilai Filsafat Hukum Keluarga; Refleksi Undang-Undang Nomor 1 tahun 1974 tentang Perkawinan". Jurnal Mimbar Hukum. 18 No. 1. Februari 2006. Yogyakarta: FH UGM;

Firdawaty, Linda. "Perlindungan Hukum Bagi Anak Karena Perkawinan Yang Fasakh Karena Melanggar Larangan Perkawinan”. Jurnal kajian Hukum Al-Adalah Vol. 7 No. 1. Juni 2008. Lampung: IAIN Raden Intan;
Hidayah, Khoirul. "Dualisme Hukum Perkawinan di Indonesia (Analisis Sosiologi Hukum Terhadap Praktik Nikah Sirri)". Jurnal Perspektif Hukum. Vol. 8 No. 1. Mei 2008. Surabaya: Universitas Hang Tuah;

Hulam, Taufiqul. "Transformasi Hukum Islam Dalam Sistem Hukum Perkawinan Orang Sakai di Desa Mandiangin Kecamatan Minas Kabupaten Biak". Jurnal Hukum Respublica. Vol. 5 No. 1. Tahun 2005. Pekanbaru: Universitas Lancang Kuning;

Irawan, Andrie. 2009. Fenomena Perkawinan Sirri Serta Dampaknya Bagi Perempuan dan Anak. Universitas Islam Indonesia Yogyakarta, http://www.docstoc.com/ docs/8436232/Dampak-Nikah-Siri-bagiPerempuan-dan-Anak, akses tanggal 7 Januari 2011;

Kedaulatan Rakyat. Nikah Siri Berdampak Buruk Pada Masa Depan Anak, http://www. $\mathrm{krjogja}$.com/news/detail/21438/www. krjgogja.com, akses tanggal 7 Januari 2011;

Kompas, http://www2.kompas.com/ver1/Perempuan/0706/25/102054.htm, akses pada tanggal 6 Januari 2011;

Pemkab Tulung Agung, Yang Perlu Diketahui Tentang Nikah Siri atau Nikah Di Bawah Tangan,http://www. tulungagung.go.id/ index.php/component/k2/itemlist/user/ 89 bagian hukum, di akses tanggal 11 Januari 2011;

Rofiq, Ahmad. 2000. Hukum Islam di Indonesia. Jakarta: PT. Raja Grafindo Persada;

Susetyo, Heru. "Revisi Undang-Undang Perkawinan". Jurnal Lex Jurnalica. 4 No. 2. April 2007 Universitas Indonusa Esa Unggul;

Talib, Sajuti. 1996. Receptio A Contrario, Hubungan Hukum dan Tata Hukum Islam. Jakarta: Rajawali Grafindo;

Widiastuti. "Beberapa Faktor Penyebab Pasangan Suami Isteri Melakukan Pernikahan di Bawah Tangan". Jurnal Eksplorasi. Vol. XX No. 1. Tahun 2008. LPPM Slamet Riyadi. 